Agr. Biol. Chem., 38 (4), 755 761, 1974

\title{
Purification and Properties of Phage HM 7-Induced Lytic Enzyme of Clostridium saccharoperbutylacetonicum ${ }^{\dagger}$
}

\author{
Motoyoshi Hongo, Yasutaka TaHara and Seiya Ogata \\ Laboratory of Applied Microbiology, Department of Agricultural Chemistry, \\ Kyushu University, Fukuoka, Japan
}

Received September 12, 1973

\begin{abstract}
A lytic enzyme was isolated from phage HM 7-induced lysate of Clostridium saccharoperbutylacetonicum, and purified about 200 -fold by precipitation with ammonium sulfate, gel filtration with Sephadex G-75 and ampholine isoelectric focusing. The purified lytic enzyme had an apparent homogeneity on disc-electrophoresis, and the character of acidic protein showing isoelectric point at $\mathrm{pH} 4.0$. The molecular weight of lytic enzyme was estimated to be about 100,000 from the result of SDS-polyacrylamide gel electrophoresis. The optimum $\mathrm{pH}$ for the lytic enzyme activity was 6.5 . Maximum activity occurred at 30 to $35^{\circ} \mathrm{C}$, and at the ionic strength of $0.04 \mathrm{M}$ or above. The lytic enzyme activity was stimulated about $140 \%$ by $10^{-3} \mathrm{M}$ EDTA. The lytic enzyme lysed the living cells, but it had a narrow specificity which was restricted to a certain species of Clostridium such as $\mathrm{Cl}$. saccharoperbutylacetonicum. $\mathrm{Cl}$. butyricum, $\mathrm{Cl}$. botulinum, $\mathrm{Cl}$. sporogenes, and $\mathrm{Cl}$. thiaminolyticum.
\end{abstract}

The production of phage and the release of phage particles are generally accompanied by the lysis of the producer organisms. The cellular lysis is caused by the breakdown of the cell wall by the phage-induced lytic enzyme (endolysin). Phage-induced lytic enzymes are found in phage-infected organisms or induced lysogenic organisms." The presence of phage-induced lytic enzyme have been reported in various phage-bacteria systems. ${ }^{2 \sim 11}$ It is said that phage-induced lytic enzymes have a limited specificity in their lytic spectra. Recently, the possibility of using the lytic enzymes to study the chemical structure of the bacterial cell wall has greatly increased the interest in phage-induced lytic enzymes for their substrate specificity and other specificity as same as autolytic enzymes of normally growing organisms. ${ }^{12 \sim 15)}$ They may also use as the specific pharmarcological materials against some pathogenic bacteria. The bacteria of Clostridium species were neither lysed by egg white lysozyme, nor lysed by known lytic enzymes

$\uparrow$ Lytic Enzymes Active on Clostridium Species. Part. I. This work was presented at the Meeting of Nishinihon Division of the Agricultural Chemical Society of Japan, held at Miyazaki, October 21, 1972. from microbial origins. We are searching for lytic enzymes active on the bacteria of Clostridium species including pathogenic species such as $\mathrm{Cl}$. botulinum, $\mathrm{Cl}$. perfringens and $\mathrm{Cl}$. tetani.

This paper deals with the purification and general properties of phage HM 7-induced enzyme of $\mathrm{Cl}$. saccharoperbutylacetonicum as the first work of lytic enzymes active on Clostridium species. The action of the lytic enzyme on the cell wall peptidoglycan will be published in this Journal.

\section{MATERIALS AND METHODS}

Bacteria and phage. Phage HM 7 (ATCC 27022-B) and its host strain Nl-504 (ATCC 27022) of Cl. saccharoperbutylacetonicum ${ }^{16.171}$ were used throughout the work. Many bacterial species belonging to Clostridium, Bacillus, and other aerobic bacteria were also used in this work.

Media and cultural conditions. The growth of strain NI-504 was at $30^{\circ} \mathrm{C}$ under reduced atmospheric pressure $\left(5\right.$ to $10 \mathrm{~mm} \mathrm{Hg}^{2}$ in TYA medium ${ }^{1 \hat{6}}$, which contained ( $\mathrm{g} /$ /iter distilled water): glucose, 40 ; Bactotryptone (Difco), 6; yeast extract (Daigo Eiyo Kagaku Co.), 2 ; ammonium acetate, $3 ; \mathrm{KH}_{2} \mathrm{PO}_{4}, 0.5 ; \mathrm{MgSO}_{4}$. $7 \mathrm{H}_{2} \mathrm{O}, 0.4 ; \mathrm{FeSO}_{4} \cdot 7 \mathrm{H}_{2} \mathrm{O}, 0.01$; at $\mathrm{pH} 6.5$. To obtain a young exponentially growing culture, fresh medium was inoculated with sufficient cells to produce an initial 
optical density (OD) of 0.10 at $660 \mathrm{~nm}$, and unless otherwise mentioned the culture was incubated until its $\mathrm{OD}_{660}$ became $0.30\left(10^{8} \mathrm{cells} / \mathrm{ml}\right)$. In a large scale preparation for the purification of lytic enzyme or its substrate, bacterial cells were grown with standing in 5-liter flasks. For the test of lytic spectrum of lytic enzyme, many Clostridium species were also grown in TYA medium under the same anaerobic conditions, and Bacillus subtilis, Escherichia coli, and other aerobic bacteria were grown at $37^{\circ} \mathrm{C}$ or $30^{\circ} \mathrm{C}$ with shaking in nutrient broth supplemented with $5 \mathrm{~g}$ glucose and $2 \mathrm{~g}$ yeast extract per liter ( $\mathrm{pH} 7.0)$.

Turbidity measurement. Optical density (OD) of the culture or cell suspension was measured at $660 \mathrm{~nm}$ with a photoelectric colorimeter (model 7A, Tokyo Koden Co. or type-101, Hitachi Co.).

Preparation of phage lysate. The bacterial culture at $\mathrm{OD}_{660}$ of 0.30 was infected with phage HM 7 at moi of 1 to 3 under the presence of $2 \times 10^{-3} \mathrm{M} \mathrm{Ca}^{2+}$, and incubated for $15 \mathrm{hr}$ at $30^{\circ} \mathrm{C}$. The lysate was centrifuged at $10,000 \times g$ for $10 \mathrm{~min}$ to remove whole cells and cell debris.

Purification of lytic enzyme. Ammonium sulfate was added to the lysate until $60 \%$ saturation was achieved. After storage for $20 \mathrm{hr}$ at $2^{\circ} \mathrm{C}$, the resulting precipitate was collected by centrifuging at $10,000 \times g$ for $20 \mathrm{~min}$. The sediment was resuspended in onefortieth volume of $0.067 \mathrm{M}$ phosphate buffer ( $\mathrm{pH} 6.5$ ), and recentrifuged at $55,000 \times g$ for $60 \mathrm{~min}$ to remove phage particles. The supernatant was dialyzed against 50-fold of $0.067 \mathrm{M}$ phosphate buffer $\left(\mathrm{pH} \mathrm{6.5)}\right.$ at $2^{\circ} \mathrm{C}$ for $24 \mathrm{hr}$. The resulting dialysate was applied to a column of Sephadex G-75, which was equilibrated with the same buffer. The fractions having lytic enzyme activity were eluted with the same buffer. Ammonium sulfate precipitation was then performed on the collected fractions as described above. The resulting dialysate was dissolved in $0.067 \mathrm{M}$ phosphate buffer ( $\mathrm{pH}$ 6.5). This enzyme solution from gel filtration was applied to isoelectric focusing by using carrier ampholine. After dialysis against $0.067 \mathrm{M}$ phosphate buffer, the purified enzyme solution was stocked at $2^{\circ} \mathrm{C}$ until used.

Isoelectric focusing. Isoelectric focusing was performed with a $110 \mathrm{ml-LKB}$ electrofocusing column containing carrier ampholine with a $\mathrm{pH}$ range of 3 to 10 . Electrophoresis was carried out by the potential gradient of 400 to $900 \mathrm{~V}$ for $48 \mathrm{hr}$, maintaining column temperature at $4^{\circ} \mathrm{C}$ by circulating child water. After electrophoresis, the ampholine was fractionated to $2 \mathrm{ml}$ aliquots and the $\mathrm{pH}$ of each fraction was measured with a pH meter (Hitachi Horiba Model M-5).

Preparation of substrate for lytic enzyme. The formalin-treated cells were prepared as follows. The harvested cells of strain Nl-504 in logarithmic phase were exposed for $30 \mathrm{~min}$ at room temperature to $0.067 \mathrm{M}$ phosphate buffer ( $\mathrm{pH} 6.5)$ containing $5 \%(\mathrm{v} / \mathrm{v})$ formalin. The treated cells were washed twice with cold $0.067 \mathrm{M}$ phosphate buffer (without formalin), and suspended with the same buffer. Other various bacteria were exposed to formalin as same as strain N1-504.

Assay of lytic enzyme activity. Lytic enzyme activity was assayed by the decrease in turbidity of formalin-treated cells. The assay mixture contained $4.0 \mathrm{ml}$ of formalin-treated cells in $0.067 \mathrm{M}$ phosphate buffer ( $\mathrm{pH} 6.5$ ), and $1.0 \mathrm{ml}$ of enzyme solution. The initial $\mathrm{OD}_{660}$ was adjusted to 0.60 . Turbidity was measured at $10 \mathrm{~min}$ intervals for $60 \mathrm{~min}$ at $30^{\circ} \mathrm{C}$, and units for lytic activity were calculated from the following equation: Units $=1000 \times \Delta \mathrm{OD}_{660} / \mathrm{min}$. Specific activity was defined as the number of units per milligram of protein. Protein was determined as described by Lowry et al. ${ }^{18 \text { r }}$

Polyacrylamide gel electrophoresis. The procedure was performed by the same method as described by Davis ${ }^{19}$ using $7.5 \%$ polyacrylamide gel electrophoresis at pH 9.4. A sample containing about $10 \mu \mathrm{g}$ of lytic enzyme was mixed with a sample of gel solution, and the mixture was layered on the upper gel (column size: $0.5 \times 5.0 \mathrm{~cm}$ ). The electrophoresis was carried out at $2.5 \mathrm{~mA}$ per a gel column at room temperature for 90 min. After electrophoresis, gel was fixed with $10 \%$ trichloroacetic acid, and stained with $0.5 \%$ amido black in $20 \%$ acetic acid, and then destained with $7 \%$ acetic acid.

Determination of molecular weight. The molecular weight of lytic enzyme was determined by the method of SDS-polyacrylamide gel electrophoresis as described by Weber and Osborn. ${ }^{20}$ A sample containing about $10 \mu \mathrm{g}$ of lytic enzyme and $10 \mu \mathrm{g}$ of each protein having known molecular weight was layered on the upper gel (column size: $0.6 \times 9.0 \mathrm{~cm}$ ). The molecular weight of these known proteins were as follows: $\gamma$-Globulin (Sigma Chem. Co.) $; 169,000$, Bovine albumin (Schwarz \& Mann Co.); 67,000, Ovalbumin (Schwarz \& Mann Co.); 45,000, Chymotrypsinogen A (Schwarz \& Mann Co.); 25,000. The electrophoresis was carried out at $8 \mathrm{~mA}$ per a gel column at room temperature for $5 \mathrm{hr}$. Fixation, staining and destaining after electrophoresis was performed by the same method described above. Mobility was calculated as distance of migration per length of gel.

\section{RESULTS AND DISCUSSION}

Production of lytic enzyme after phage infection

In a preliminary work, the best conditions for the production of phage HM 7-induced 


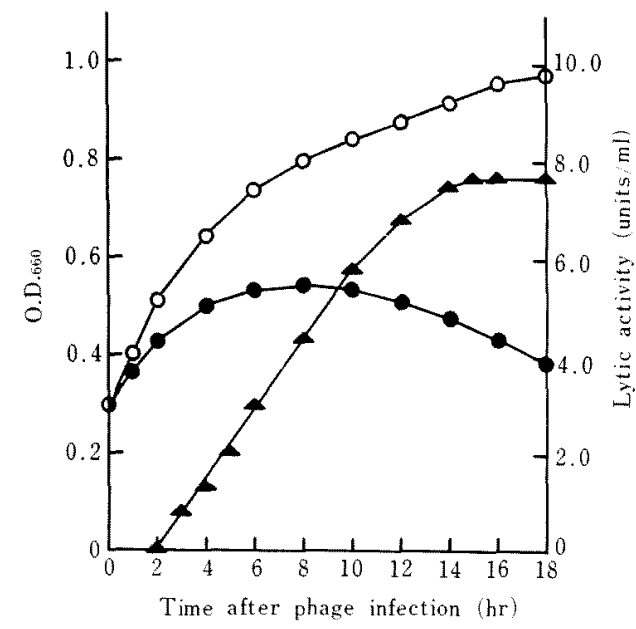

FIg. 1. Time Course of Production of Phage HM 7-Induced Lytic Enzyme.

The host cells $\left(\mathrm{OD}_{660}: 0.30\right)$ in the logarithmic phase were infected with phage HM 7 at moi of 3 , and the cultivation was continued at $30^{\circ} \mathrm{C}$. The infected culture was withdrawn at the various ages, and was immediately centrifuged at $55,000 \times g$ for $60 \mathrm{~min}$ to remove whole cells, cell debris and phage particles. The supernatant was assayed for the lytic enzyme activity as described in MATERIALS AND METHODS.

$O$, normal growth;, phage infected growth; $\boldsymbol{\Lambda}$, lytic enzyme activity.

lytic enzyme were examined. The lytic enzyme activity was reached to a maximum in the lysate when the following conditions were used: Phage HM 7 was added to the cells of $\mathrm{OD}_{660}$ of 0.30 in the logarithmic phase at the moi of 1 to 3 .

Figure 1 shows the time courses of the lysis curve of host cells and the production of lytic enzyme under the best conditions. The lytic enzyme appeared in the lysate at $3 \mathrm{hr}$ after addition of phage HM 7. The activity of lytic enzyme increased as time proceeded, reaching its maximum at $15 \mathrm{hr}$. On the other hand, the lysate had usually $1 \times 10^{10} \mathrm{PFU}$ per milliliter of phages. Lytic enzyme would be accumulated by the recycles of phage infection without the loss of its activity. No activity of phageinduced enzyme was detected in the uninfected culture. The presence of autolytic enzyme in the normally growing culture of the host cells was demonstrated by Ogata and Hongo. ${ }^{21}$ However, phage HM 7-induced lytic enzyme was clearly different from autolytic enzyme in their substrate specificity and optimum $\mathrm{pH}$ : the former was active against formalin-treated cells as well as isolated cell walls, whilst the latter was only active on isolated cell walls; the former's optimum $\mathrm{pH}$ was 6.5 as described in following section, whilst the latter's optimum $\mathrm{pH}$ was 4.5 to 5.0 .

\section{Purification of lytic enzyme}

The lytic enzyme was prepared from the phage lysate which had 7 units per milliliter of lytic enzyme activity, and purified by the use of ammonium sulfate precipitation, gel filtration with Sephadex G-75 and subsequent ampholine isoelectric focusing. These procedure yielded reproducible results. The result of a typical purification is summarized in Table I. In the final purification step, the lytic enzyme was purified about 200 -fold with a $12.5 \%$ recovery of lytic enzyme activity. By use of the phage assay described by Hongo and Murata, ${ }^{16,22)}$ the Sephadex G-75 fraction as same as the purified lytic enzyme was found to be free from phage HM 7 .

Figure 2 shows the electrophoretic pattern of lytic enzyme on isoelectric focusing. A peak of lytic enzyme activity was at $\mathrm{pH} 4.0$. It was also indicated that phage HM 7-induced lytic enzyme was an acidic protein having a iso-

Table I. Purification of Phage HM 7-Induced Lytic Enzyme

\begin{tabular}{lcccccc}
\hline \multicolumn{1}{c}{ Fraction } & $\begin{array}{c}\text { Volume } \\
(\mathrm{ml})\end{array}$ & $\begin{array}{l}\text { Lytic } \\
\text { activity } \\
\text { (units/ml) }\end{array}$ & $\begin{array}{c}\text { Protein } \\
(\mathrm{mg} / \mathrm{ml})\end{array}$ & $\begin{array}{l}\text { Specific } \\
\text { activity } \\
(\text { units/mg) }\end{array}$ & $\begin{array}{c}\text { Purification } \\
\text { (fold) }\end{array}$ & $\begin{array}{c}\text { Yield } \\
(\%)\end{array}$ \\
\hline Phage-induced lysate & 1000 & 7.0 & 7.8 & 0.9 & - & 100 \\
Ammonium sulfate & 25 & 114.0 & 4.3 & 26.5 & 30 & 40.8 \\
Sephadex G-75 & 13 & 126.0 & 1.3 & 97.0 & 108 & 23.5 \\
Isoelectric focusing & 6 & 142.0 & 0.8 & 178.0 & 198 & 12.5 \\
\hline
\end{tabular}


electric point at $\mathrm{pH} 4.0$.

The result of the electrophoretic analysis in

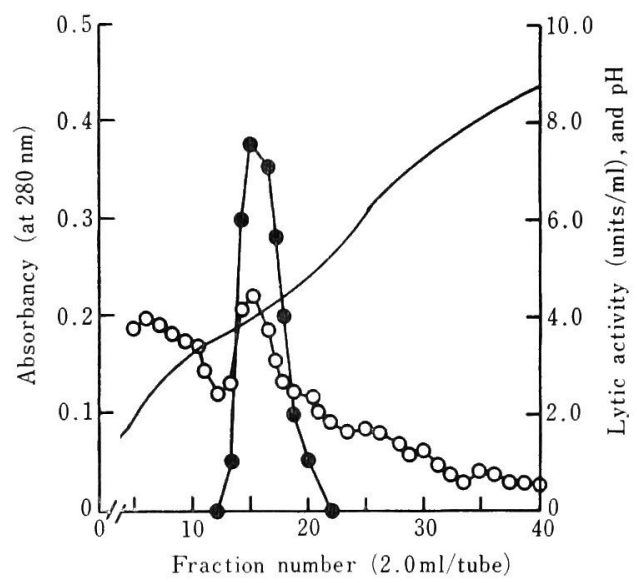

Fig. 2. Electrophoresis of Phage HM 7-Induced Lytic Enzyme on Isoelectric Focusing.

The enzyme solution filtrated by Sephadex G-75 was applied on a $110 \mathrm{ml}-\mathrm{LKB}$ column, and electrophoresis was carried out with the potential gradient of 400 to $900 \mathrm{~V}$ for $48 \mathrm{hr}$, maintaining column temperature at $4^{\circ} \mathrm{C}$ by circulating child water. Lytic enzyme activity was assayed as described in MATERIALS AND METHODS.

-, lytic enzyme activity; $\mathrm{O}, \mathrm{OD}_{280},-, \mathrm{pH}$.

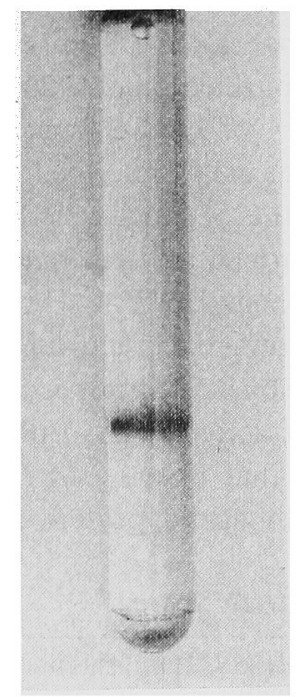

FIG. 3. Polyacrylamide Gel Electrophoresis of

Purified Phage HM 7-Induced Lytic Enzyme at pH 9.4.

Ten micrograms of lytic enzyme was applied on a column $(0.5 \times 5.0)$ and electrophoresis was carried out at $2.5 \mathrm{~mA}$ per column at room temperature for $90 \mathrm{~min}$. polyacrylamide gel for the purified lytic enzyme is shown in Fig. 3. One band was clearly present. It was evident that the purified lytic enzyme was homogenous in the electrophoresis.

\section{Molecular weight}

Molecular weight of lytic enzyme was determined by the method of SDS-polyacrylamide gel electrophoresis. As shown in Fig. 4, a

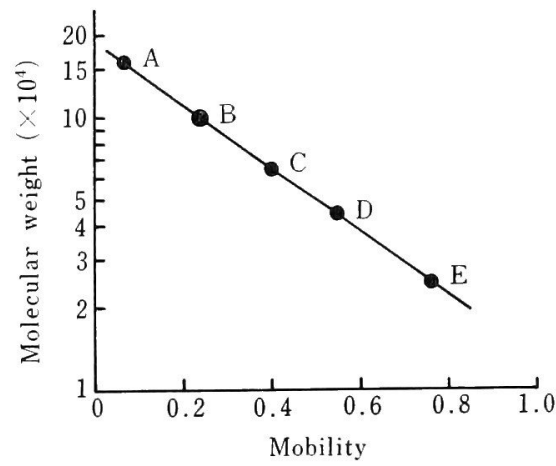

FIG. 4. Molecular Weight Determination of Phage HM 7-Induced Lytic Enzyme by Method of SDSPolyacrylamide Gel Electrophoresis.

Ten microgram of each protein was applied on a column $(0.6 \times 9.0)$ and electrophoresis was carried out at $8.0 \mathrm{~mA}$ per column at room temperature for $5 \mathrm{hr}$.

A, $\gamma$-globuline; B, phage HM 7-induced lytic enzyme; $\mathrm{C}$, albumin (bovine); D, ovalbumin; E, chymotrypsinogen $\mathrm{A}$.

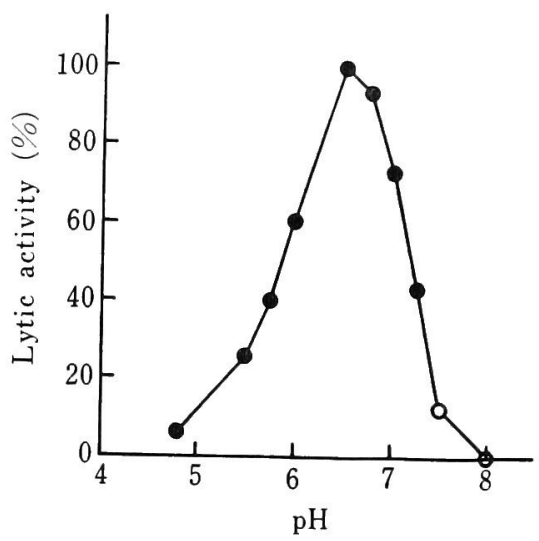

FIG. 5. Effect of $\mathrm{pH}$ on Lytic Enzyme Activity.

Lytic enzyme activity was assayed as described in MATERIALS AND METHODS. Maximum lytic enzyme activity: 12 units.

- $0.067 \mathrm{M}$ phosphate buffer; $\mathrm{O}, 0.05 \mathrm{M}$ Tris- $\mathrm{HCl}$ buffer. 


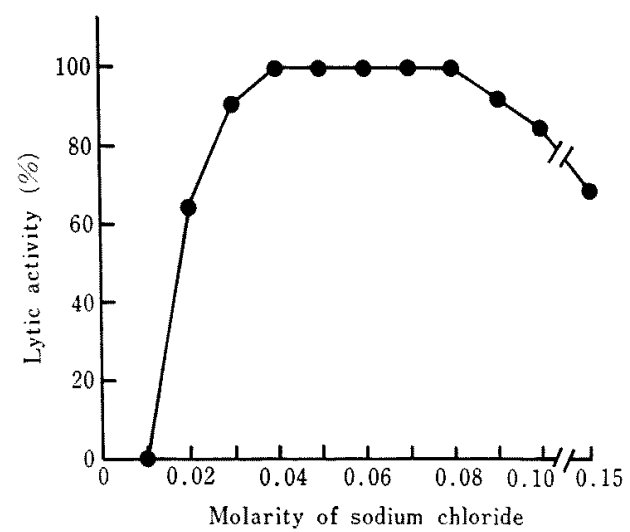

FIG. 6. Effect of Ionic Strength on Lytic Enzyme Activity.

The enzyme solution was dialyzed at $2^{\circ} \mathrm{C}$ against 0.01 M phosphate buffer ( $\mathrm{pH}$ 6.5). Various molarities of $\mathrm{NaCl}$ were then added to assay mixtures to determine the optimum ionic strength for the lytic enzyme activity. Lytic enzyme activity was assayed as described in Methods. Maximum lytic enzyme activity: 12 units.

Table II. Effect of Bivalent Cations and EDTA ON LyTIC ENZYME ACTIVITy

Each assay mixture contained 12 units of lytic enzyme activity.

\begin{tabular}{lcc}
\hline Salt addition & Molarity & $\begin{array}{c}\text { Lytic activity } \\
(\%)\end{array}$ \\
\hline none & - & 100 \\
$\mathrm{MgSO}_{4}$ & $10^{-4}$ & 102 \\
& $10^{-3}$ & 40 \\
$\mathrm{CaCl}_{2}$ & $10^{-4}$ & 85 \\
& $10^{-3}$ & 50 \\
$\mathrm{CoCl}_{2}$ & $10^{-4}$ & 100 \\
& $10^{-3}$ & 77 \\
$\mathrm{CdCl}_{2}$ & $10^{-4}$ & 0 \\
$\mathrm{CuSO}_{4}$ & $10^{-4}$ & 0 \\
$\mathrm{NiSO}_{4}$ & $10^{-4}$ & 90 \\
& $10^{-3}$ & 30 \\
EDTA & $10^{-4}$ & 110 \\
& $10^{-3}$ & 142 \\
\hline
\end{tabular}

linear relationship was obtained among the molecular weight of four proteins. From the distance of migration of lytic enzyme located on the standard curve, the molecular weight of lytic enzyme was calculated to be about 100,000 .

\section{Properties of lytic enzyme}

l) Optimum $\mathrm{pH}$. The effect of $\mathrm{pH}$ on the lytic enzyme activity was examined in $0.067 \mathrm{M}$ phosphate buffer or $0.05 \mathrm{M}$ Tris- $\mathrm{HCl}$ buffer of various $\mathrm{pH}$. As shown in Fig. 5, the enzyme had a sharp optimum at $\mathrm{pH} 6.5$. No activity was shown at alkaline $\mathrm{pH}$.

2) Optimum temperature. The effect of temperature on the lytic enzyme activity was examined over a range of 20 to $50^{\circ} \mathrm{C}$. The optimum temperature was 30 to $35^{\circ} \mathrm{C}$. Lytic

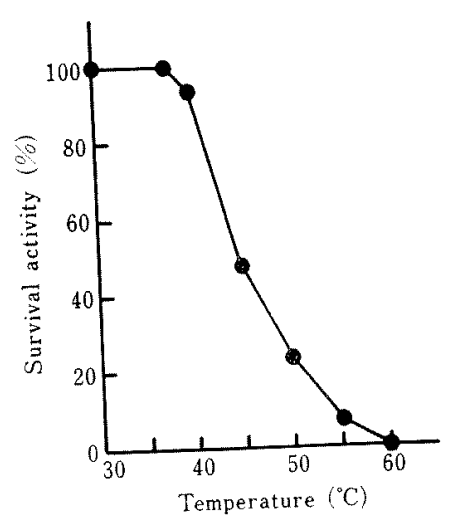

FIG. 7. Stability of Lytic Enzyme at Various Temperatures.

The enzyme solution was heated for 5 min at various temperatures indicated, and then immediately cooled at $2^{\circ} \mathrm{C}$. Residual lytic enzyme activity was assayed as described in MATERIALS AND METHODS. Initial lytic enzyme activity: 12 units.

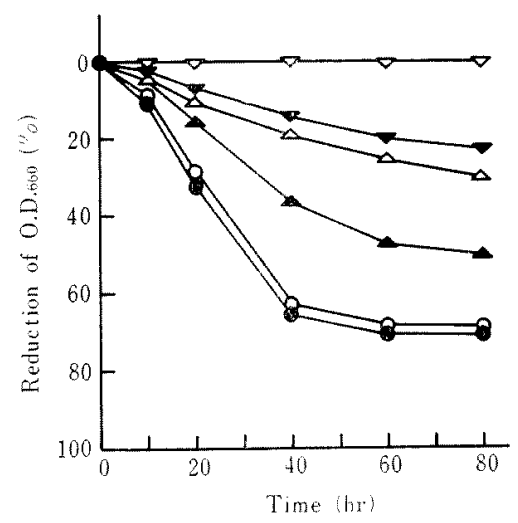

FIG. 8. Action of Phage HM 7-Induced Lytic Enzyme toward Formalin-Treated Cells of Various Clostridium Species.

- Cl. saccharoperbutylacetonicum Nl-4, N1-504; $\mathrm{O}, \mathrm{Cl}$. kaneboi and $\mathrm{Cl}$. sporogenes; $\mathbf{\Delta , C l}$. butyricum; $\triangle, \mathrm{Cl}$. thiaminolyticum; $\mathbf{\nabla}, \mathrm{Cl}$. botulinum; $\nabla, \mathrm{Cl}$. acetobutylicum. 
activity abruptly decreased at $40^{\circ} \mathrm{C}$ or above.

3) Optimum ionic strength. As shown in Fig. 6, the lytic enzyme activity increased with the ionic strength to a value of $0.04 \mathrm{M}$. Optimum ionic strength was observed at the ranges of 0.04 to $0.08 \mathrm{M}$.

\section{4) Effect of bivalent cations and EDTA on} lytic enzyme activity. The effect of various bivalent cations and EDTA on the lytic enzyme activity is shown in Table II. The lytic enzyme activity was stimulated $110 \%$ and $142 \%$ by the addition of $10^{-4} \mathrm{M}$ and $10^{-3} \mathrm{M}$ EDTA, respectively. On the other hand, all bivalent cations tested inhibited the lytic enzyme activity at a concentration of $10^{-3} \mathrm{M} . \mathrm{Cu}^{2+}$ and $\mathrm{Cd}^{2+}$ completely inhibited the enzyme action even at $10^{-4}$ M. Phage HM 7-induced lytic enzyme did not require bivalent cations for its action, but was inhibited by them. It was also considered that the stimulatory effect of EDTA was due to the cancellation of action of bivalent cations which were contaminated in the reaction mixture.

5) Thermostability. The survival activity of lytic enzyme after heating for $5 \mathrm{~min}$ at various temperatures are shown in Fig. 7. The inactivation of lytic enzyme activity occurred at above $40^{\circ} \mathrm{C}$. A 5-min exposure at $50^{\circ} \mathrm{C}$ and $60{ }^{\circ} \mathrm{C}$ resulted in $75 \%$ and $99 \%$ inactivation, respectively. This result indicates that phage HM 7-induced lytic enzyme is relatively heat labile.

Table III. Lytic Spectrum of Phage HM 7-Induced Lytic Enzyme

Each assay mixture contained 12 units of lytic enzyme activity.

\begin{tabular}{|c|c|c|c|}
\hline \multirow[t]{2}{*}{ Bacteria tested } & \multicolumn{2}{|c|}{$\begin{array}{l}\text { Sensitivity to phage HM } 7- \\
\text { induced lytic enzyme }\end{array}$} & \multirow[t]{2}{*}{$\begin{array}{l}\text { Sensitivityal } \\
\text { to phage }{ }^{a} \mathbf{M} 7\end{array}$} \\
\hline & Intact cells ${ }^{b}$ & Heated cells ${ }^{b}$ & \\
\hline \multicolumn{4}{|l|}{$\begin{array}{l}\text { Clostridium } \\
\text { saccharoperbutylacetonicum }\end{array}$} \\
\hline NI-504 (ATCC 27022) & + & - & $t$ \\
\hline $\mathrm{Nl}-4(\operatorname{ATCC} 13564)^{e\}}$ & + & - & - \\
\hline Cl. acetobutylicum & - & - & - \\
\hline Cl. butyricum & + & - & - \\
\hline Cl. botulinum (IFO 3733) & + & - & - \\
\hline Cl. kaneboi & + & - & - \\
\hline Cl. sporogenes (IFO 12636) & + & - & - \\
\hline Cl. thiaminolyticum (IFO 3969) & + & - & - \\
\hline Bacillus cereus (IFO 3001) & - & - & - \\
\hline B. circulans (IFO 3329) & - & - & - \\
\hline B. megaterium (IFO 3003) & - & - & - \\
\hline B. polymyxa (IFO 3020) & - & - & - \\
\hline B. subtilis (IFO 12210) & - & - & - \\
\hline Aerobacter aerogenes (IFO 3317) & - & - & - \\
\hline Escherichia coli (IFO 13168) & - & - & - \\
\hline Micrococcus lysodeikticus (IFO 3333) & - & - & - \\
\hline Pseudomonas aeruginosa (IFO 3755) & - & - & - \\
\hline Sarcina lutia & - & - & - \\
\hline Staphylococcus aureus (IFO 3060) & - & - & - \\
\hline
\end{tabular}

a) Sensitivity of various bacteria to phage HM 7 was assayed by double layer method used usually ${ }^{16,221}$

b) Intact cells: Formalin-treated cells or living cells. Heated cells: Formalin-treated cells or living cells boiled for $2 \mathrm{~min}$.

These cells were suspended in $0.067 \mathrm{M}$ phosphate buffer ( $\mathrm{pH} 6.5$ ).

c) Strain Nl-4 is original strain for a series of phage-resistant strain of $\mathrm{Cl}$. saccharoperbutylacetonicum. Phage HM 7 is specific for strain Nl-504 alone, whereas the other 11 phages attacked the original strain $\mathrm{Nl}-4 .^{16}$ 
Activity spectrum of lytic enzyme

The activity spectrum is shown in Table III. Phage HM 7 was highly specific for strain N1-504 alone, whereas its induced lytic enzyme lysed the formalin-treated cells and normal growing cells of various kinds of bacteria of Clostridium species except $\mathrm{Cl}$. acetobutylicum. It was also evident that the activity spectrum of lytic enzyme was broader than that of phage itself. Many aerobic bacteria were not lysed by this enzyme. Sensitivity of living cells to the lytic enzyme was almost identical to the formalin-treated cells, but in the living cells, the lytic action of autolytic enzyme took part in cellular lysis. Young, actively growing cells and their formalin-treated cells were the most sensitive to lysis. This sensitivity decreased with the age of the culture and reached a minimum when the cells entered the stationary phase of growth. Among the bacteria of Clostridium species found to be sensitive to this enzyme, $\mathrm{Cl}$. saccharoperbutylacetonicum, $\mathrm{Cl}$. kaneboi and $\mathrm{Cl}$. sporogenes were the most sensitive to lysis, as shown in Fig. 8. Twelve units of enzyme lysed $70 \%$ of their cells within $60 \mathrm{~min}$. The sensitivity of these bacteria decreased in order of $\mathrm{Cl}$. saccharoperbutylacetonicum, $\mathrm{Cl}$. Kaneboi and $\mathrm{Cl}$. sporogenes $>$ $\mathrm{Cl}$. butyricum $>\mathrm{Cl}$. thiaminolyticum and $\mathrm{Cl}$. botulinum. Boiling the cells for $2 \mathrm{~min}$ caused them to become extremely resistant to lysis by this enzyme.

These results indicate that phage HM 7induced lytic enzyme have a high substrate specificity and a narrow lytic spectrum.

Acknowledgement. The authors thank Mr.S. Inouye for his technical assistance in part of this work which was partly supported by a Grant-in-Aid for
Scientific Research from the Ministry of Education of Japan.

\section{REFERENCES}

1) G.S. Stent, "Molecular biology of bacterial viruses," W. H. Freeman and Co., San Francisco, 1963, p. 80.

2) J. S. Murphy, Virology, 4, 563 (1957).

3) F. Jacob and C. R. Fuerst, J. Gen. Microbiol., 18, 518 (1958).

4) W. Weidel and W. Katz, Z. Naturforsch., 16b, 156 (1961).

5) B. Reiter and J. O. Oram, J. Gen. Microbiol., 32, 29 (1963).

6) N. E. Welker, J. Virol., 1, 617 (1967).

7) J. M. Goepfert and H. B. Naylor, ibid., 1, 701 (1967).

8) A. Tsugita and M. Inoyue, J. Biol. Chem., 243, 391 (1968).

9) L. W. Black and D. S. Hogness, ibid.; 244, 1968 (1969).

10) H. Ishiwa and K. Yokokura, Japan. J. Microbiol., 15, 539 (1971).

11) S. A. Sonstein, J. M. Hammel and A. Bondi, $J$. Bacteriol., 107, 499 (1971).

12) G. D. Shockman, Bacteriol. Rev., 29, 345 (1965).

13) F. E. Young, J. Biol. Chem., 241, 3462 (1966).

14) J. Coyette and J.M. Ghuysen, Biochemistry, 9, 2952 (1970).

15) T. Kawata and K. Takumi, Japan. J. Microbiol., 15, 1 (1971).

16) M. Hongo and A. Murata, Agr. Biol. Chem., 29, 1135 (1965).

17) S. Ogata, N. Nagao, Z. Hidaka and M. Hongo, ibid., 33, 1541 (1969).

18) O. H. Lowry, N. J. Rosenbrough, A. L. Farr and R. T. Randall, J. Biol. Chem., 193, 265 (1951).

19) B. J. Davis, Ann. New York Acad. Sci., 121, Art. 2, 404 (1964).

20) K. Weber and M. Osborn, J. Biol. Chem., 244, 4406 (1969).

21) S. Ogata and M. Hongo, J. Gen. Appl. Microbiol., 19, 251 (1973); J. Gen. Microbiol., in press.

22) M. Hongo and A. Murata, Agr. Biol. Chem., 29, $1140(1965)$. 